\title{
The Implementation of EMU (English Moslem Union) Approach in Developing Islamic Studies and English Competence of UNTIDAR Moslem Students (A Case Study Conducted at TIDAR University)
}

\author{
Farikah $^{1}$ \\ Tidar University, Indonesia \\ Correspondence: farikahfaradisa@gmail.com
}

\begin{abstract}
The purpose of this research is to describe the implementation of EMU (English Moslem Union) Approach in developing islamic studies and English competence among the moslem students of Tidar University (UNTIDAR). EMU Approach is a way of developing Islamic studies as well as English competence. Through EMU, the students of UNTIDAR study Islam as well as English with Halaqoh model. Halaqoh is a term used in Islamic education. Halaqoh (circle) is used to describe a group with about 8 or 10 persons who learn islamic studies regularly. One of them is as murrabi (teacher) and the others are as mutarabbi (students). This descriptive qualitative study employed in-depth interviews, and on-site observation in collecting the data. Following Milles and Hubberman's theory (1994), the writer analyzed the data through data reduction, data display, conclusion and verification. The triangulation was employed in checking the validity of the data. The results show that the implementation of EMU through Halaqoh model is an effective way to develop Islamic studies and English competence of Tidar University students. It can be seen from two indicators. The first, it can be seen from the students' characters in terms of nature, attitude and habit.The second is from the students' competence in English through discussion activities.
\end{abstract}

Keywords: EMU; English competence; Islamic studies; halaqoh model 


\section{INTRODUCTION}

Education has long been a topic of intense discussion. The quality of education itself is a phenomenon which always becomes attention among the society. Education is one of the most important aspects in human development. In general, education is to transmit a common set of beliefs, values, norms, understanding from the adult generation to its youths. Education is often defined as human efforts towards building human character based on the values commonly held in a specific community and culture (Hasbullah, 2006). A West-Asian philosopher, Syed Husain \& Syed Ali Ashraf (1979) stated that "education signifies the transmission of experiences from one generation to other". A well-known Malaysian philosopher, Syed Muhammad Al-Naquib Al-Attas (1979) defines education as the "process of instilling something into the human being". These definitions show that education aims towards achieving one common goal - human development (Ahmad, 2000).

Dealing with character education, nowadays, the importance of this is gaining momentum among people in our society, especially educators. Moreover, in the last several years the government have stressed the importance of character in education through the curriculum. Talking about character education, religious frameworks of education have became key areas of interest and Islamic education has great potential in building character. The term "education" from an Islamic context generally refers to the term at-tarbiyah (educate). The term at-tarbiyah (educate) is an Arabic derived from the word rabb, which entails a number of different meanings such as to grow, develop, preserve, maintain and manage a situation so that it does not change (Al-Qurtubi, 1987).

As we know, Islam looks at education as a form of worship (ibadah) where Moslems share a common set of values based on the Quran (the fundamental and most reliable source for many fields of knowledge) and Sunnah. Hassan, K. (1989) describes Education from the Islamic perspective, as a long life process of preparing an individual to actualize his role as a vicegerent (Khalifah) of Allah on earth and thereby contribute fully to the reconstruction and development of his society in order to achieve well-being in this world and hereafter. The concept of Islamic education requires the development of the overall human potential including the spiritual, intellectual, emotional and physical aspects. This development is based on the teachings of the Qur'an and Hadith and seeks to produce humans who have taqwa (piety) and dedicate themselves to worshipping God (Shah, 2013; Nor et al., 2012).

This descriptive qualitative aims to describe the implementation of EMU (English Moslem Union) approach in developing islamic studies and English competence among moslem students of Tidar University (UNTIDAR). EMU is a part of UKAI (Unit Kegiatan 
Agama Islam) Arribath Untidar which deals with development of islamic studies and English competence as well. In other words, EMU approach is a way of developing Islamic studies as well as English competence among the Moslem students of UNTIDAR. Through EMU, the students of UNTIDAR study Islam as well as English with Halaqoh model. Halaqoh is a term used in Islamic education (Lubis, 2010). The Arabic word halaqoh means a ring and it is used to refer to circle of islamic knowledge. Historically, the transmission of knowledge usually took place in the mosque, a practice that can be traced back to Propet. Halaqoh (circle) is used to describe a group with about 8 or 10 persons who learn islamic studies regularly. One of them is as murrabi (teacher) and the others are as mutarabbi (students). The process of halaqoh is done regularly every week.

The mission of EMU through this halaqoh model is in line with the aims of teaching Islamic education. As stated by Darajat (2001), the teaching of Islamic education must have the following characteristics:

a. the develop and strengthen faith in Allah;

b. to provide and enrich religious knowledge;

c. to build skills that can be practised;

d. to guide and develop the individual potential which we possess since birth;

e. to build and develop social feelings and good character; and

f. The provision of knowledge and skills that can be applied and developed in all fields of work to fend for their lives (professional workforce)

Based on the explanation, the main objective of Islamic religious education is to prepare students to have Islamic knowledge that can and must be applied in daily life as a form of worship to the Creator of the universe. At the same time, students will also gain English competence and many other benefits. In other words, EMU through halaqoh model is an effort to develop good character of UNTIDAR moslem students as well as English competence.

In this descriptive qualitative study, the writer employed in-depth interviews, and on-site observation in collecting the data. The writer as the elder of UKAI Arribath UNTIDAR observed the EMU activities and interviewed the members of EMU related to EMU activities and the benefits of joining EMU. In addition to that, the writer also observed the members of EMU in dayly activities especially in campus. Following Milles and Hubberman's theory (1994), the writer analyzed the data through data reduction, data display, conclusion and verification. The triangulation was employed in checking the validity of the data. 


\section{DISCUSSION}

The results of the implementation of EMU (English Moslem Union) approach in developing islamic studies and English competence among the students of Tidar University (UNTIDAR) can be seen in two aspects. The first is to know the implementation of EMU approach in developing islamic studies. It can be seen from the students' characters in terms of nature, attitude and habit.The second is the implementation of EMU approach in developing English Competence. It can be seen from the students' competence in English through discussion activities.

\section{The Implementation of EMU approach in developing Islamic studies}

The first purpose of present study was to know the implementation of EMU approach in developing the Islamic studies of the moslem students of Tidar University. Islamic studies here refers to integrated process of imparting Islamic knowledge. This can be seen from the students' characters in terms of nature, attitude and habit. The indicators are inferred from Darajat's theory on the characteristics of teaching of Islamic education (2001). These are the following.

a. the develop and strengthen faith in Allah;

b. to provide and enrich religious knowledge;

c. to build skills that can be practised;

d. to guide and develop the individual potential which we possess since birth;

e. to build and develop social feelings and good character; and

f. The provision of knowledge and skills that can be applied and developed in all fields of work to fend for their lives (professional workforce).

Based on the results of site observation and interview, it can be seen that through EMU approach, the UNTIDAR moslem students are motivated to study Islam and have good character. It can be inferred from the number of the moslem students who join EMU. Some of the topics of EMU discussion are as follows.
a. Five pillars of Islam
b. Prophet's Moral Teachings
c. Trust and honesty
d. Fulfillment of promise
e. Sincerity

In addition to that, the writer observed the moslem students from the following aspects.

a. Cooperation

The moslem students who join EMU will actively involve in group work activities in the classroom. They also like to help others.

b. Responsibility

The students tend to do individual work well and ask forgiveness for their fault. They also will return back the things they borrow. 
c. Tolerance

The students do not disturb others and they will accept the different opinions.

d. Honesty

They do not do cheating in the tests and always do every assignment.

e. Discipline

They tend to do every job on time. They have good commitment to attend and take their learning seriously.

Besides that, the writer interviewed some students who joined EMU. Almost all of them stated that through EMU, it will be more interesting to study Islam. By joining this, they can learn Islamic studies through creative ways. It is not monotoneous. In addition to that, they believe that seeking knowledge is a duty up on every moslem. When they leave thier home to learn, they are rewarded for every step they take in the pursuit of knowledge.

\section{The Implementation of EMU approach in developing English competence}

The second purpose of this study was to know the implementation of EMU approach in developing the English competence of UNTIDAR moslem students. Based on the observation, it can be seen that the moslems students who join EMU gradually improve their English competence. They are motivated to be able to speak english since the EMU discussions are in english. Based on the writer' observation, it can be inferred that there is a great improvement in english competence of the moslem students of Tidar University after joining EMU. Since the writer also taugh English in Indonesian and Economic Study department for first semester students, the write observed directly toward the development of English competence of UNTIDAR moslem students of those deapartments.

\section{CONCLUSSION}

The results show that the implementation of EMU through Halaqoh model is an effective way to develop Islamic studies and English competence of UNTIDAR moslem students. It can be seen from two indicators. The first, it can be seen from the students' characters in terms of nature, attitude and habit.The second is from the students' competence in English through discussion activities. 
THE IMPLEMENTATION OF EMU (ENGLISH MOSLEM UNION)

\section{REFERENCES}

Ahmad, M.Y. (2000). Sejarah dan kaedah pendidikan Al-Quran. Universiti Malaya. Kuala Lumpur

Al-Qurtubi. (1987). Al-jami’ li-Ahkam al-Qur'an, Al-hay'ah al-masriyyah al-ammah lilKitab. Cairo.

Daradjat, Z. (2001). Metodologi pengajaran agama Islam, Cet. Ke II. Bumi Aksara: Jakarta. Hasbullah (2006), Dasar-dasar ilmu pendidikan. Raja Grafindo Persada: Jakarta.

Hassan, M. K. (1989). Values education framework based on Islamic concepts and precepts. Jurnal Pendidikan Islam. Vol.2, No.3.

Husain, S.S., \& Ashraf, S.A. (1979), Crisis in Muslim education. Hodder and Stoughton. London\& King Abdulaziz University: Jeddah.

Lubis, Hadi, Satria. (2010). Menggairahkan perjalanan halaqah. Yogyakarta: Pro-U Media.

Miles, M. B., \& Huberman, A. M.. (1994) Qualitative data analysis. Thousand Oaks: Sage Publication.

Gross, Z. et al. (Ed). Gender, religion and education in a chaotic postmodern world. Springer: New York, London. 